\title{
Antioxidant, Antimicrobial, Anti-diarrheal and Analgesic Activities of Diospyros malabarica (Desr.) Kostel
}

\author{
Md. Moniruzzaman ${ }^{1}$, Md. Ruhul Kuddus ${ }^{2}$, A.M. Sarwaruddin Chowdhury ${ }^{1}$ \\ and Mohammad A. Rashid ${ }^{2}$ \\ ${ }^{1}$ Department of Applied Chemistry \& Chemical Engineering, Faculty of Engineering and Technology \\ University of Dhaka, Dhaka-1000, Bangladesh \\ ${ }^{2}$ Department of Pharmaceutical Chemistry, Faculty of Pharmacy, University of Dhaka \\ Dhaka-1000, Bangladesh
}

(Received: July 30, 2018; Accepted: August 30, 2018; Published: January 17, 2019)

\begin{abstract}
The present study was designed to evaluate the antioxidant, antimicrobial, antidiarrheal and analgesic activities of methanol extract of Diospyros malabarica (Desr.) Kostel buds growing in Bangladesh. The total phenolic content of methanol extract of D. malabarica and its Kupchan fractions was determined and expressed in gallic acid equivalent (GAE). In the DPPH free radical scavenging assay, the aqueous soluble fraction of the methanol extract of $D$. malabarica revealed maximum free radical scavenging activity having $\mathrm{IC}_{50}$ value of $6.17 \mu \mathrm{g} / \mathrm{ml}$. In antimicrobial assay, all the test samples displayed prominent antimicrobial activity against the test organisms under in vitro conditions. Among these, the carbon tetrachloride soluble fraction was found to exhibit the highest activity against Bacillus cereus, Salmonella Typhi, Salmonella Paratyphi, and Candida albicans with the zone of inhibition as 32, 30, 28 and $30 \mathrm{~mm}$, respectively. In evaluation of antidiarrheal activity, the D. malabarica extracts showed significant anti-diarrheal potential in a dose dependent manner. During the evaluation of analgesic activity by radiant heat tail-flick method, the plant extract at $400 \mathrm{mg} / \mathrm{kg}$ b.w. exhibited highest elongation (373.04\%) as compared to morphine (472.48\%). On the other hand, in acetic acid-induced writhing test, the extract at 200- and 400-mg/kg b.w. showed 61.11 and $66.67 \%$ inhibition of writhing in mice model, respectively as compared to $68.06 \%$ inhibition produced by the standard diclofenac-Na. The findings of this study justify some of the traditional uses of $D$. malabarica and reveal the bioactivity of the plants. Further studies are required to isolate and identify the bioactive compounds.
\end{abstract}

Key words: Diospyros malabarica, antioxidant, antimicrobial, antidiarrheal, analgesic.

\section{Introduction}

Medicinal plants serve as a prominent source of biologically active molecules and lead structures for the development of new therapeutic agent with enhanced activity and reduced toxicity. According to the world health organization (WHO), about $80 \%$ of the population in Africa and the majority of the populations in Asia and Latin America use traditional medicines for their primary healthcare needs. But the uses of most of these plants have no scientific basis (Ghani, 2003). Therefore, evaluation of medicinal plants with important biological activity is an essential task to discover new lead compounds from natural sources (Kuddus et al., 2013; Ibrahim et al., 2017).

Diospyros malabarica (Desr.) Kostel (FamilyEbenaceae) is a medium size evergreen plant which is native to the Indian Subcontinent. In Bangladesh, the plant is known as Gaub. It is a long-lived, very slow-growing tree reaching $15-35 \mathrm{~m}$ in height. The plants are mainly used for furniture and wood carvings also used as raw material for boats and

Correspondence to: Mohammad A. Rashid; Tel.: +88-02-9661900-73, Extn. 8137; Fax: +88-02-9667222;

E-mail: r.pchem@yahoo.com 
constructions (Ravikumar et al., 2014). The ripe fruits are edible. The unripe fruits are powerful astringent and contain tannin that can be used for dyeing. The plant possesses antifertility activity (Choudhary et al., 1990) and is useful for the treatment of dysentery and menstrual problems (Mondal et al., 2006). The bark possesses hypoglycemic, antiviral, antiprotozoal (Mondal et al., 2006) and hepatoprotective (Mondal et al., 2005) activity. Different phytochemicals such as $\beta$ sitosterol, betulin, betulinic acid, oleanolic acid, lupeol and gallic acid have been isolated from the leaf and bark of $D$. malabarica (Kavatagimath and Jalapure, 2015).

As part of our continuing studies on medicinal plants of Bangladesh (Moniruzzaman et al., 2018; Miah et al., 2017), we conducted assays for biological activities of methanol extract of Bangladeshi medicinal plant D. malabarica as well as to find out the logical evidence for its folk uses.

\section{Materials and Methods}

Plant materials: The tender buds (baby fruit) of D. malabarica were collected from Muksudpur, Gopalgonj in Bangladesh, in October 2016 and identified by the taxonomist of Bangladesh National Herbarium, Mirpur, Dhaka where a voucher specimen has been deposited (DACB-43523). The collected sample was at first washed properly, and then sun dried about 30 consecutive days. Finally the dried crispy bud was ground into a coarse powder using a well cleaned grinding machine at the laboratory of Department of Applied Chemistry and Chemical Engineering, University of Dhaka. The powder materials (about $350 \mathrm{~g}$ ) of tender buds of D. malabarica were macerated in 2.5 liter of $99.8 \%$ methanol for 30 days and finally filtered through Whatman filter paper number 1 . The filtrate was concentrated using rotary evaporator at $40^{\circ} \mathrm{C}$ under reduced pressure. About $5 \mathrm{~g}$ of the concentrated extract was subjected to solvent-solvent partitioning following the modified Kupchan method (VanWagenen et al., 1993) to yield petroleum ether, carbon tetrachloride, chloroform and aqueous soluble fractions. Then the crude extract and its Kupchan fractions were studied separately for the assay of biological activities.

Drugs and reagents: Methanol, Tween-80, loperamide (Square Pharmaceuticals Ltd), castor oil, normal saline (Opsonin Pharmaceuticals Ltd), morphine (Gonoshasthaya Pharmaceuticals Ltd), acetic acid, diclofenac-Na (Essential Drugs Company Ltd) were collected from local market. All other chemicals and solvents were of analytical grade.

Experimental animal: Swiss Albino mice (28-30 gm) of either sex aged 4-5 weeks were collected from the Animal Resources Branch of the International Centre for Diarrheal Diseases and Research, Bangladesh (icddr,b). They were housed in standard polypropylene cages and kept at room temperature $\left(24 \pm 2^{\circ} \mathrm{C}\right)$ and relative humidity (60-70\%) in a $12 \mathrm{hrs}$ light-dark cycle and are fed with icddr,b formulated diet and water ad libitum.

Total phenolics analysis: The antioxidant effect of phytochemicals is mainly due to phenolic components, such as flavonoids, phenolic acids, and phenolic diterpenes (Shahidi et al., 1992). Total phenolic content of D. malabarica extractives was measured by employing published method (Skerget et al., 2005) involving Folin-Ciocalteu reagent as an oxidizing agent and gallic acid as standard.

Determination of free radical scavenging activity: The antioxidant activity (free radical scavenging activity) of the methanolic crude extract of D. malabarica and its Kupchan fractions on the stable radical 1,1- diphenyl-2-picrylhydrazyl (DPPH) was determined by the method developed by BrandWilliams et al., 1995.

Antimicrobial activity: The antimicrobial activity of methanolic crude extract of D. malabarica and its Kupchan fractions were investigated by disc diffusion method (Bauer et al., 1966) using standard ciprofloxacin $(30 \mu \mathrm{g} / \mathrm{disc})$ and fluconazole (30 $\mu \mathrm{g} / \mathrm{disc})$ as references.

Anti-diarrheal activity: Anti-diarrheal activity of the crude methanol extract of D. malabarica was carried out by castor oil-induced diarrhea in mice (Shoba and Thomas 2001). Experimental animals 
(Swiss albino mice) were divided into negative control, positive control and two test groups consisting of four mice in each group. The negative control group received vehicle (1\% Tween-80 in water) at $10 \mathrm{ml} / \mathrm{kg} \mathrm{b.w.} \mathrm{orally} \mathrm{while} \mathrm{the} \mathrm{positive}$ control group received loperamide $(50 \mathrm{mg} / \mathrm{kg}$ b.w.) orally. The test group received the methanolic extract of D. malabarica at 200 - and $400-\mathrm{mg} / \mathrm{kg}$ b.w. orally. Thirty minutes intervals were given to ensure proper absorption of the administered drugs. Then, $1 \mathrm{ml}$ of castor oil was administrated to each mouse for inducing diarrhea. Each animal was placed in an individual case, the floor of which was lined with blotting paper. Each of the mice was observed for four hours. Each time a mouse had given stool was recorded. The average of total number of stool given by the test group, and the control group was compared and the percent inhibition of defecation in mice was calculated by using the following equation

$\%$ Inhibition $=\left(\mathrm{M}_{\mathrm{C}}-\mathrm{M}_{\mathrm{T}}\right) / \mathrm{M}_{\mathrm{C}} \times 100$

where, $\mathrm{M}_{\mathrm{C}}=$ Mean defecation of control and $\mathrm{M}_{\mathrm{T}}$ $=$ mean defecation of test sample.

\section{Analgesic activity}

Radiant heat tail-flick test: The central analgesic activity of $D$. malabarica extract was determined by radiant heat tail-flick method (D'amour et al., 1941; Hussain et al., 2014). In this experiment, the test groups received the plant extract (200- and 400$\mathrm{mg} / \mathrm{kg}$ b.w. orally), while the positive and negative control mice were treated with morphine $(4 \mathrm{mg} / \mathrm{kg}$ b.w.) subcutaneously and normal saline, respectively. Thirty minutes after administration, the tail of each mouse was kept immersed in hot water at $54^{\circ} \mathrm{C}$. The time required to withdraw the tail (tail flick) was recorded. The tail flicking time was measured by stopwatch. Then the percent (\%) time of elongation due to the effect of various fraction and standard were calculated using the following formula:

$\%$ elongation of reaction time $=$ (Average reaction time of the test group - Average reaction time of control group)/Average reaction time of control group.

Acetic acid-induced writhing test: The peripherial analgesic activity of D. malabarica was determined by the acetic acid-induced writhing inhibition method (Koster et al., 1959) in mice. In this experiment, the negative control group received normal saline orally while the positive control group received diclofenac-Na $\quad(50 \quad \mathrm{mg} / \mathrm{kg} \quad$ b.w. $)$ subcutaneously. The experimental groups received the plant extract at $200-$ and $400-\mathrm{mg} / \mathrm{kg}$ b.w. orally. Thirty minutes later the writhing inducing chemical, acetic acid solution was administered intraperitoneally to each experimental animal. The percent (\%) inhibition of writhing in comparison to control group was taken as an index of analgesia and was calculated using the following formula:

$\%$ Inhibition $=\left[\left(\mathrm{W}_{\mathrm{C}}-\mathrm{W}_{\mathrm{T}}\right) \times 100\right] / \mathrm{W}_{\mathrm{C}}$

where, $\mathrm{W}_{\mathrm{C}}$ is the average number of writhing in control group and $\mathrm{W}_{\mathrm{T}}$ is the average number of writhing in the test animal.

\section{Results and Discussion}

The present study was designed to evaluate the antioxidant, antimicrobial, anti-diarrheal and analgesic properties of $D$. malabarica and the results have been summarized in tables 1-5.

The total phenolics analysis and DPPH radical scavenging activity are commonly widely used methods for screening the antioxidant activity of plant extract. Both these methods were applied to evaluate the antioxidant activities of the $D$. malabarica. In this experiment, the highest amount of phenolics were observed in the crude methanol extract $(12.87 \mathrm{mg}$ of $\mathrm{GAE} / \mathrm{gm})$ demonstrating the moderate antioxidant potentials. In the DPPH free radical scavenging assay, all plant extracts produced moderate to high DPPH scavenging activity with the maximum scavenging activity being observed in the aqueous soluble fraction $\left(\mathrm{IC}_{50}=6.17 \mu \mathrm{g} / \mathrm{ml}\right)$ followed by methanolic crude extract $\left(\mathrm{IC}_{50}=8.4 \mu \mathrm{g} / \mathrm{ml}\right.$ ) (Table 1). Based on the results, the water and methanol extracts which are more polar solvent extracts, were more effective antioxidants compared to the non-polar petroleum ether extract in DPPH assay. This data is also supported by previous studies (Mondal et al., 2006). 
During screening for antimicrobial activity by disc diffusion assay, all the plant samples of $D$. malabarica except aqueous soluble fraction at concentrations of $400 \mu \mathrm{g} / \mathrm{ml}$ exhibited varying degrees of antimicrobial activity (zone of inhibition $=$ 10-32 $\mathrm{mm}$ ) against the test organisms (Table 2). The crude methanolic extract exhibited significant activity against Candida albicans $(28 \mathrm{~mm})$, Bacillus cereus
(25 mm), Bacillus megaterium (24 mm) and Vibrio parahemolyticus $(25 \mathrm{~mm})$ while the petroleum ether soluble fraction showed maximum activity against Vibrio parahemolyticus $(29 \mathrm{~mm})$. Among all the samples, the carbon tetrachloride soluble fraction presented strong antimicrobial activity against most of the test organisms. Table 2 clearly shows that Bacillus cereus

Table 1. Total phenolic content and free radical scavenging activity of $D$. malabarica.

\begin{tabular}{ccc}
\hline $\begin{array}{c}\text { Test } \\
\text { sample }\end{array}$ & $\begin{array}{c}\text { Total phenolic content } \\
\text { (mg of GAE/g of dried extract) }\end{array}$ & $\begin{array}{c}\text { DPPH Free radical scavenging } \\
\text { activity }\left(\mathrm{IC}_{50} \mu \mathrm{g} / \mathrm{ml}\right)\end{array}$ \\
\hline ME & 12.87 & 8.4 \\
PESF & 0.90 & 217.02 \\
CTSF & 3.49 & 77.48 \\
CSF & 5.90 & 21.33 \\
AQSF & 10.90 & 6.17 \\
BHT & - & 10.70 \\
AA & - & 2.73 \\
\hline
\end{tabular}

Here, $\mathrm{ME}=$ methanolic crude extract of $D$. malabarica PESF = petroleum ether soluble fraction; CTSF = carbon tetrachloride soluble fraction; $\mathrm{CSF}=$ chloroform soluble fraction; $\mathrm{AQSF}=$ aqueous soluble fraction of the methanolic extract of . malabarica , BHT = Butylated hydroxyl toluene, $\mathrm{AA}=$ Ascorbic acid.

Table 2. Antimicrobial activity of different fractions of $D$. malabarica.

\begin{tabular}{|c|c|c|c|c|c|}
\hline \multirow{2}{*}{ Test microorganisms } & \multicolumn{5}{|c|}{ Diameter of zone of inhibition (mm) } \\
\hline & ME & PESF & CFSF & AQSF & Ciprofloxacin \\
\hline \multicolumn{6}{|l|}{ Gram positive } \\
\hline Bacillus cereus & 25 & 22 & 32 & - & 39 \\
\hline B. megaterium & 24 & 18 & 25 & - & 42 \\
\hline Stapphylococcus aureus & 22 & 26 & 29 & 10 & 45 \\
\hline Sarcina lutea & 14 & 18 & 23 & 8 & 45 \\
\hline \multicolumn{6}{|l|}{ Gram negative } \\
\hline Escherichia coli & 22 & 26 & 27 & 9 & 43 \\
\hline Pseudomonas aeruginosa & 19 & 25 & 24 & 14 & 44 \\
\hline Salmonella Paratyphi & 20 & 25 & 28 & - & 40 \\
\hline S.Typhi & 22 & 27 & 30 & - & 41 \\
\hline Shigella boydil & 16 & 21 & 26 & - & 42 \\
\hline Sh. dysenteriae & 18 & 22 & 27 & 12 & 42 \\
\hline Vibrio mimicus & 22 & 23 & 26 & - & 40 \\
\hline Vibrio parahemolyticus & 25 & 29 & 28 & - & 43 \\
\hline Fungi & & & & Flucor & \\
\hline Aspergillus niger & 10 & 21 & 22 & - & 40 \\
\hline Candida albicans & 28 & 20 & 30 & - & 41 \\
\hline Sacharomyces cerevisiae & 15 & 18 & 20 & - & 38 \\
\hline
\end{tabular}

— : No inhibition zone observed 
Table 3. Anti-diarrheal activity of methanol crude extract of $D$. malabarica.

\begin{tabular}{lcc}
\hline Test Group & $\begin{array}{c}\text { No. of diarrheal feces } \\
\text { Mean } \pm \text { SEM }\end{array}$ & $\begin{array}{c}\text { (\%) Reduction of } \\
\text { diarrheal feces }\end{array}$ \\
\hline $\begin{array}{l}\text { Negative control } \\
\text { Loperamide } \\
(50 \mathrm{mg} / \mathrm{kg} \text { b.w. })\end{array}$ & $6.33 \pm 2.26$ & - \\
$\mathrm{ME}$ & $3.00 \pm 1.06$ & 52.63 \\
$(200 \mathrm{mg} / \mathrm{kg}$ b.w. $)$ & $4.67 \pm 1.68$ & 26.32 \\
$\mathrm{ME}$ & $3.33 \pm 1.22$ & 47.37 \\
$(400 \mathrm{mg} / \mathrm{kg}$ b.w. $)$ & & \\
\hline
\end{tabular}

(32 mm), Salmonella Typhi (30 mm), Salmonella Paratyphi $(28 \mathrm{~mm})$, Candida albicans $(30 \mathrm{~mm})$ are highly susceptible to the carbon tetrachloride soluble fraction of $D$. malabarica extract. The aqueous soluble fraction was found to be less active against the test strains.

In the castor oil-induced diarrhea in mice, the crude methanol extract of D. malabarica produced marked anti-diarrheal effect in dose-dependent manner, as shown in table 3 . Here, the plant extract at the dose of 200- and 400-mg/kg b.w. demonstrated reduction of diarrheal feces by $26.32 \%$ and $47.37 \%$, respectively when compared with standard drug loperamide. Castor oil can induce diarrhea in mice via several mechanisms. Ricinoleic acid, the hydrolysis product of castor oil, stimulates secretion of fluid and electrolytes of the small intestine which speed up the intestinal transit (Helmut et al., 1972). The anti-diarrheal activity of the extract against experimentally induced diarrhea by castor oil may be attributed to an anti-electrolyte permeability action. The mechanism of antidiarrheal action of the plant extract also may be via the inhibition of the effect of the ricinoleic acid on prostaglandin $E_{2}$ receptors (Tripathi 2008).

The central analgesic effect of methanol extract of D. malabarica is presented in table 4. In this test, the plant extract effectively elongated the reaction time. The percent (\%) elongation time was recorded at 30, 60 and $90 \mathrm{~min}$ after administration of drug samples in the experimental mice. About $30 \mathrm{~min}$ after administration, the plant extract, at the doses of 200and $400-\mathrm{mg} / \mathrm{kg}$ b.w. revealed elongation of reaction time by $112.36 \%$ and $170.37 \%$, respectively while the standard morphine showed $226.10 \%$ of elongation. After $90 \mathrm{~min}$, the crude extract at 400$\mathrm{mg} / \mathrm{kg}$ b.w. exhibited highest elongation as $373.04 \%$ compared to $472.48 \%$ by morphine. The central analgesic property was found to increase till $90 \mathrm{~min}$ and then decreased with time.

Table 4. Central analgesic activity of methanol extract of D. malabarica.

\begin{tabular}{|c|c|c|c|c|c|c|c|c|}
\hline \multirow[b]{2}{*}{ Test Group } & \multicolumn{4}{|c|}{ Mean of tail immersion \pm SEM } & \multicolumn{4}{|c|}{$\%$ elongation } \\
\hline & $0 \mathrm{~min}$ & $30 \mathrm{~min}$ & $60 \mathrm{~min}$ & $90 \mathrm{~min}$ & $\begin{array}{c}0 \\
\min \end{array}$ & $\begin{array}{c}30 \\
\min \end{array}$ & $\begin{array}{l}60 \\
\min \end{array}$ & $\begin{array}{l}90 \\
\min \end{array}$ \\
\hline Negative control & $1.31 \pm 0.05$ & $1.27 \pm 0.05$ & $1.48 \pm 0.05$ & $1.50 \pm 0.05$ & - & - & - & - \\
\hline $\begin{array}{c}\text { Morphine } \\
\text { (4 mg/kg b.w.) }\end{array}$ & $1.30 \pm 0.10$ & $4.16 \pm 0.11$ & $6.27 \pm 0.16$ & $8.58 \pm 0.50$ & -1.02 & 226.10 & 323.19 & 472.48 \\
\hline $\begin{array}{c}\text { ME } \\
\text { (200 mg/kg b.w.) }\end{array}$ & $1.31 \pm 0.03$ & $2.71 \pm 0.05$ & $4.31 \pm 0.30$ & $3.79 \pm 0.65$ & -0.44 & 112.36 & 191.16 & 153.03 \\
\hline $\begin{array}{c}\mathrm{ME} \\
\text { (400 mg/kg b.w.) }\end{array}$ & $1.29 \pm 0.06$ & $3.45 \pm 0.23$ & $4.93 \pm 0.19$ & $7.09 \pm 0.92$ & -1.84 & 170.37 & 232.81 & 373.04 \\
\hline
\end{tabular}


Table 5. Peripheral analgesic activity of methanol extract of $D$. malabarica.

\begin{tabular}{|c|c|c|c|c|c|c|c|}
\hline \multirow{2}{*}{ Test Group } & \multicolumn{4}{|c|}{ Writhing count } & \multirow{2}{*}{$\begin{array}{c}\text { No. of writhing } \\
\text { Mean } \pm \text { SEM }\end{array}$} & \multirow{2}{*}{$\%$ Writhing } & \multirow{2}{*}{$\begin{array}{l}\text { \% Inhibition of } \\
\text { writhing. }\end{array}$} \\
\hline & M1 & M2 & M3 & M4 & & & \\
\hline Negative control & 22 & 13 & 19 & 18 & $18.0 \pm 2.29$ & 100 & - \\
\hline $\begin{array}{l}\text { Diclofenac-Na } \\
\text { (50 mg/kg b.w.) }\end{array}$ & 7 & 5 & 5 & 6 & $5.75 \pm 0.58$ & 31.94 & 68.06 \\
\hline $\begin{array}{l}\text { ME } \\
\text { (200 mg/kg b.w.) }\end{array}$ & 6 & 7 & 7 & 8 & $7.00 \pm 0.29$ & 38.89 & 61.11 \\
\hline $\begin{array}{l}\text { ME } \\
\text { (400 mg/kg b.w.) }\end{array}$ & 7 & 6 & 5 & 6 & $6.0 \pm 0.50$ & 33.33 & 66.67 \\
\hline
\end{tabular}

In acetic acid-induced writhing model, analgesic activity was determined by comparing the percent writhing inhibition by the crude extracts of buds of D. malabarica in comparison to the control and the standard groups. The more the writhing inhibition by the test groups, the more the positive activity. Acetic acid causes inflammatory pain by inducing capillary permeability and liberating endogenous substances like $\mathrm{PGE}_{1}$ and $\mathrm{PGE}_{2}$ that excite pain nerve ending (Dev et al., 2015). The analgesic activity of bud extract of $D$. malabarica could be due to the inhibitory effect on release of $\mathrm{PGE}_{1}, \mathrm{PGE}_{2}$ that stimulate pain nerve endings similar to that of diclofenac-Na and NSAIDs. Thus, the reductions in the number of writhing in mice indicate that bud extract of $D$. malabarica might exert analgesic activity by inhibition of prostaglandin synthesis. In this study, D. malabarica extract at 200- and 400$\mathrm{mg} / \mathrm{kg}$ b.w. showed $61.11 \%$ and $66.67 \%$ inhibition of writhing, respectively as compared to $68.06 \%$ inhibition produced by the standard diclofenac-Na (Table 5). Both in the acetic acid-induced writhing and tail flick method, the plant extract showed significant analgesic activity compared to the commonly used analgesic drugs e.g., morphine, diclofenac-Na. As the extract appeared to be active in both animal models of nociception, it may possess peripherally and centrally acting compounds for its antinociceptive action. However, further studies are necessary to identify the exact mechanism of analgesic activity of $D$. malabarica and to isolate the bioactive compounds responsible for this pharmacological activity.

\section{Conclusion}

The bud extract of $D$. malabarica has been found to be effective in microbial infection, diarrhea and pain. Further studies are needed to isolate the bioactive compounds which are responsible for these bioactivities.

\section{Acknowledgements}

The authors wish to acknowledge the supports of State University of Bangladesh for providing laboratory facilities to carry out the experiments.

\section{References}

Bauer, A.W., Kirby, W.M., Sherris, J.C. and Turck. M. 1966. Antibiotic susceptibility testing by a standardized single disk method. Am. J. Clin. Pathol. 45, 493-496.

Brand-Williams, W., Cuvelier, M.E. and Berset, C. 1995. Use of free radical method to evaluate antioxidant activity. Lebensm Wiss Technol. 28, 25-30.

Choudhary, D.N., Singh, J.N., Verma, S.K. and Singh, B.P. 1990. Antifertility effects of leaf extracts of some plants in male rats. Indian J. Exp. Biol. 28, 714-716.

D'amour F.E. and D. L. Smith, 1941. A method for determining loss of pain sensation. J. Pharmacol. Exp. Therapeutics 72, 74-79.

Dev, S.K., Shukla, A., Choudhury, P.K. and Singh, G.K. 2015. Analgesic and anti-nociceptive activity of hydroethanolic extract of Capparis decidua (Forssk.) Edgew. Asian J. Pharm. Pharmacol. 1, 40-44.

Ghani, A. 2003. Medicinal Plants of Bangladesh: Chemical constituents and uses. $2^{\text {nd }}$ edition, Asiatic society of Bangladesh, Dhaka. 
Helmut, V.A., Paul, J.T. and Sidney, F.P. 1972. Effect of oleic and ricinoleic acids on net jejunal water and electrolyte moment perfusion studies in man. J Clin Invest. 53, 374-379.

Hussain, F., Ganguly, A., Hossain, M.S. and Rahaman, S.M.A. 2014. Analgesic and anti-diarrhoeal activity of roots in experimental animal model. Dhaka Univ. J. Pharm. Sci. 13, 57-62.

Ibrahim, Kuddus, M.R., Hossain, M.A. and Rashid, M.A. 2017. Preliminary phytochemical screenings and pharmacological activities of three medicinal plants of Bangladesh. Dhaka Univ. J. Pharm. Sci. 16, 195-203.

Kavatagimath, S.A. and Jalalpure, S.S. 2015. Screening of ethanolic extract of Diospyros malabarica Desr. bark for anti-diabetic and antioxidant potential. Indian $J$. Pharm. Edu. Res. 50, 179-189.

Koster, R., Anderson, M. and Beer, E.J. 1959. Acetic acid for analgesic screening. Federation Proceedings 18, 412-416.

Kuddus, M.R., Rumi, F., Haque, M.R., Hassan, M.A. and Rashid, M.A. 2013. Assessment of antioxidant, antimicrobial and cytotoxic properties of fruits of Melocanna baccifera (Roxb.) Kurz. Turkish J. Pharm. Sci. 10, 185-192.

Miah, M.M., Das, P., Mridha, S.A., Kuddus, M.R. and Rashid, M.A. 2017. Biological activities of Digera muricata (L.) Mart. available in Bangladesh. Dhaka Univ. J. Pharm. Sci. 16, 195-203.

Mondal, S.K., Chakraborty, G., Gupta, M. and Mazumder, U.K. 2005. Hepatoprotective activity of Diospyros malabarica bark in carbon tetrachloride intoxicated rats. European Bull. Drug Res. 13, 25-30.
Mondal, S.K., Chakraborty, G., Gupta, M. and Mazumder, U.K. 2006. In vitro antioxidant activity of Diospyros malabarica Kostel bark. Indian J. Exp. Biol. 44, $39-44$.

Moniruzzaman, M., Kuddus, M.R., Haque, M.R., Chowdhury, A.M.S. and Rashid, M.A. 2018. Stereospermum suaveolens (Roxb.) DC. shows potential in vivo and in vitro bioactivities. Dhaka Univ. J. Pharm. Sci. 17, ASAP, 2018 (June).

Ravikumar, A., Vengalrao, P., Shobhana, K. and Kishore, S. 2014. An overview on Diospyros malabarica. Int. J Novel Trends Pharm. Sci. 4, 93-96.

Shahidi, F., Janitha, P.K. and Wanasundara, P.D. 1992. Phenolic antioxidants. Critic. Rev. Food Sci. Nutr. 32, 67-103.

Shoba, F.G. and M.Thomas. 2001. Study of antidiarrhoeal activity of four medicinal plants in castor oil induced diarrhea. J Ethnopharmacol. 76, 73-76.

Skerget, M., Kotnik, P., Hadolin, M., Hras, A., Simonic, M. and Knez, Z. 2005. Phenols, proanthocyanidins, flavones and flavonols in some plant materials and their antioxidant activities. Food Chem. 89, 191-198.

Tripathi, K.D. 2008. Essentials of Medical Pharmacology. New Delhi: Jaypee Brothers Medical Publishers (P) Ltd. Drugs for constipation and diarrhoea. pp. 651664.

VanWagenen, B.C., Larsen, R., Cardellina, J.H., Ran dazzo, D., Lidert, Z.C., Swithenbank, C. 1993. Ulosantoin, a potent insecticide from the sponge Ulosa ruetzleri. J. Org. Chem. 58, 335-337. 